\title{
THE INFLUENCE OF LUTHER'S VIEW OF MUSIC ON THE EMERGENCE OF THE CONCEPTS OF MUSICA POETICA AND MUSICAL RHETORIC
}

\author{
Ph.D. student ANAMARIA LUPU \\ National University of Music Bucharest
}

\begin{abstract}
Anamaria LUPU is currently a second-year student in a Scientific Doctoral Programme at the National University of Music Bucharest and at the same time a permanent teacher at the "Dinu Lipatti" National College of Arts. With a rich and almost decade-long activity in the media as a TV and radio programme editor and producer at Speranța $T V$ and Radio Vocea Speranței, the author has had the opportunity to host her own music programmes entitled "Amadeus", attended by many prestigious guests from the Romanian musical world.
\end{abstract}

\section{ABSTRACT}

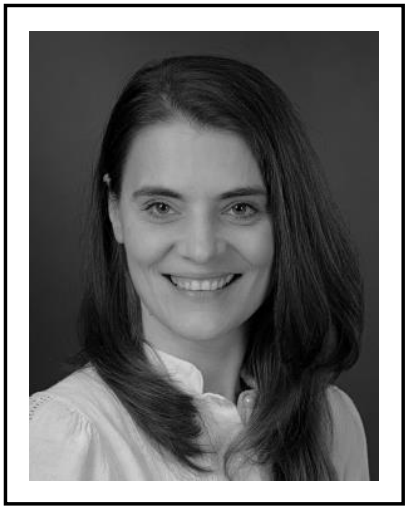

When we speak about musical rhetoric, rhetorical figures, or elements related to musica poetica, we almost always automatically think about the Baroque and, why not, about Johann Sebastian Bach's music. However, few of us realize that the roots of these notions trace back to the Renaissance, and even fewer will relate them to Martin Luther's name and the Protestant Reformation. The principles of musical rhetoric developed mainly in the North German space, although they were also present in other countries such as Italy, France and England. It was Germany, however, that in those times most enthusiastically adopted and adapted the terminology, methods and structures of ancient rhetoric. In his Musica Poetica, the German musicologist Dietrich Bartel explains the rise of musical rhetoric in Germany as a consequence of Martin Luther's view of music being embraced by the Christian believers. Over the sixteenth to eighteenth centuries, musical rhetoric was continuously enriched and perfected, generating an extremely elaborate art whose focus was to find equivalences between rhetorical figures and musical intervals. Thus, music acquired a higher degree of accuracy of expression.

Keywords: Martin Luther, Lutheran Reformation, musical rhetoric, musica poetica, theory of the affects, rhetorical figures

The period of the Renaissance and Reformation was the period that witnessed the emergence of the idea of musica poetica, which reached its full fruition during the Baroque era. Classical rhetoric, promoted by both the philosophers of Ancient Greece and those of Ancient Rome, was the source of 
inspiration not only for the arts of the word, but also for the art of music. Gioseffo Zarlino (1517-1590), the well-known theorist and composer of the Italian Renaissance, entitled his treatise on vocal polyphonic synthesis Le istitutioni harmoniche (1558), a title similar to Quintilian's treatise on rhetoric, Institutio Oratoria (35-100). In the chapter he dedicates to the construction of the subject of the fugue, Zarlino refers to the rhetorical theories of philosophers Aristotle, Cicero and Quintilian, or to the poetic art of Hermogenes and Horace ${ }^{1}$.

The principles of musical rhetoric developed mainly in the North German space, although they were also present in other countries such as Italy, France and England. It was Germany, however, that most enthusiastically adopted and adapted during this period the terminology, methods and structures of ancient rhetoric. Over the sixteenth to eighteenth centuries, musical rhetoric was continuously enriched and perfected, generating an extremely elaborate art whose focus was to find equivalences between rhetorical figures and musical intervals. Thus, music acquired a higher degree of accuracy of expression. With such a rational system, composers could calculate the audience's emotional response based on the melodic formula used, a method later known as the "theory of the affects" (Affektenlehre).

In his Musica Poetica, the German musicologist Dietrich Bartel explains the rise of musical rhetoric in Germany as a consequence of Martin Luther's view of music being embraced by the Christian believers. Luther regarded the art of sound as a divine gift, second only to the Holy Scriptures, or to theology. On the other hand, Lutheranism encouraged the use of rhetorical techniques in the preachings of the clergy, because in Lutheran schools, Latin was the language of instruction and rhetoric was one of the important disciplines. Luther believed that stronger than the simple word is the word accompanied by music, and therefore the musical rendition of the biblical text and of the corresponding affects in true sonic preachings became the main mission of Lutheran composers. The primary purpose of expressing the affects was not to delight the audience, but rather to preach the Christian gospel ${ }^{2}$. Luther was firmly convinced that music was surpassed in importance only by theology, and the role given to music by applying this principle facilitated the involvement of parishioners in the divine service. The promotion of the chorale by Luther and his colleagues was a step of major significance in the history of church music ${ }^{3}$.

1 Patrick McCreless, Music and Rethoric, in "The Cambridge History of Western Music Theory", ed. Thomas Christensen, Cambridge University Press, 2002, p. 852, quoted at

http://ligaoamenilordeculturabontideni.blogspot.com/2012/02/pasiunile-si-retorica-de-la-aristotel.html, accessed: December 29, 2019.

2 Dietrich Bartel, Musica Poetica, Musical-Rhetorical Figures in German Baroque Music, University of Nebraska Press, Lincoln and London, 1997, p. 3.

${ }^{3}$ Alexander Fisher, Music and religious change, in "The Cambridge History of Christianity - Reform and expansion 1500-1660", Edited by R. Po-Chia Hsia, Cambridge University Press, 2007, p. 388. 
The idea that music is a mathematical discipline (included in the quadrivium) and intervals are determined by numerical ratios, coming from the ancient Pythagorean thinking, was also present at that time. Pythagoras believed that the mathematical relationships that generate consonances are closely related to those responsible for the proper functioning of the human body (musica humana) and even for the structure of the entire universe (musica mundana). This theory was in harmony with the Lutheran view of the divine origin of music, the essence of the Creator being thus revealed through intervallic relationships ${ }^{1}$.

Nicolaus Listenius (1510-1538), a valuable student of Luther and Melanchthon at the University of Wittenberg, was the first to blend music into the language arts in the trivium, instead of the quadrivium, where it had been integrated until then. He was the first to draw attention to the idea of musica poetica in Rudimenta musicae planae (1533), which he later explored in more detail in the first chapter of Musica (1537), one of the most popular sixteenth-century treatises in Germany. Listenius extended the two traditional branches of music, i.e. musica theoretica (naturalis, speculativa - which tried to explain music through numbers, looking for the relationship between the universal order established by God and the vibration of each sound) ${ }^{2}$ and musica practica (artificialis - which in the German space designated the art of vocal performance as a priority $)^{3}$, by introducing a third branch, musica poetica (representing the study of composition, as an independent category from which a perfect and absolute work of art results) ${ }^{4}$. At the same time, in the Italian European space, musica practica was defined much more extensively than in the German space, comprising the application of the speculative theoretical knowledge to the practice of composition and of vocal and instrumental performance. Later, German theorists such as Johann Gottfried Walther (1684-1748) included musica poetica as a subcategory of musica practica, thus leaving the Italian classification with two main branches, while others, such as Johann Andreas Herbst (1588-1666), defined musica poetica as an independent musical category ${ }^{5}$.

If at the beginning of the sixteenth century the true musician was the one who dealt with the mathematical speculations of intervallic relationships

\footnotetext{
${ }^{1}$ Patrick McCreless, Music and Rethoric, ed. cit., p. 18.

2 George Buelow, Symposium on Seventeenth-Century Music Theory: Germany, in "Journal of Music Theory 16", no. 1/2, quoted by Helen Kin Hoi Wong, in Musica Poetica in Sixteenth-Century Reformation Germany, The Chinese University of Hong Kong, 2009, p. 33.

${ }^{3}$ John Butt, Music Education and the Art of Performance in the German Baroque, Cambridge Musical Texts and Monographs, Cambridge University Press, Cambridge, 1994, xii, quoted by Helen Kin Hoi Wong, in Musica Poetica in Sixteenth-Century Reformation Germany, The Chinese University of Hong Kong, 2009, p. 34.

${ }^{4}$ Ludwig Finscher, ed. Die Musik des 15. und 16. Jahrhunderts, vol. 3, no. 1 of Neues Handbuch der Musikwissenschaft, ed. Carl Dahlhaus (Laaber: Laaber, 1989), p. 169, quoted by Helen Kin Hoi Wong, in Musica Poetica in Sixteenth-Century Reformation Germany, The Chinese University of Hong Kong, 2009 , p. 35.

${ }^{5}$ Patrick McCreless, Music and Rethoric, ed. cit., p. 20.
} 
(musica speculativa), in the seventeenth and eighteenth centuries, the speculative and expressive components of music were brought into balance by bringing music closer to rhetoric and diminishing the importance of mathematics. The composer, then called musicus poeticus ${ }^{1}$, had the task to sonically reproduce the divine inspiration, to which the believer would resonate naturally and involuntarily, as in the principle of sympathetic vibrations.

Soon, the term musica poetica began to appear in the titles of various treatises on composition of the musicians of the time. For example, Heinrich Faber (1500-1552) wrote De musica poetica (1548), in which he defined it as "the art of shaping a musical poem" and divided it into two parts: improvisation (sortisatio) and composition (compositio), considering the latter as superior to the former. Gallus Dressler (1533-1580)2 published Praecepta musicae poeticae (1563), which contains details on the compositional process based on elements of musical rhetoric and in which he describes musica poetica both as a genre and as a musical discipline. The German composer Seth Calvisius (1556-1615) published in Erfurt, in 1592, the treatise Melopoiia Sive Melodiae Condendae Ratio, Quam Vulgo Musicam Poeticam Vocant, in which he transposes the contrapuntal system set forth by Zarlino into German compositional methods. At the same time, he discusses the close relationship between text and music in musical composition and indicates how poetic figures should be effectively set.

Joachim Burmeister (1564-1629) brings a much more detailed perspective on rhetorical figures in the treatise Musica Poetica, published in 1606 and which is also accessible online at digital.staatsbibliothek-berlin.de. The treatise develops three angles of analysis, starting from the sounds, continuing with the harmonic intervals resulting from them and ending with harmony proper, the one which stirs the emotions. He details the melodic figures inspired by rhetoric, those that are responsible for creating the affects, but on the basis of which music can be conceived objectively, according to strict rules, thus distancing itself from that note of subjectivity and interpretable. ${ }^{3}$

Elias Walther, another composer and theorist of the seventeenth century, defined musica poetica as a mathematical science which concerns itself with the creation of melodies capable of bringing the listener closer to Divinity. In this sense, music had to emphasize both the text and the affects corresponding to the ideas expressed; while the text convinces the intellect, music convinces the emotional. In his theoretical works, composer Andreas Werckmeister (1645-1706)

\footnotetext{
${ }^{1}$ Ibidem.

2 Ibidem.

${ }^{3}$ Joachim Burmeister, Musica Poetica, translated by Agathe Sueur et Pascal Dubreuil, Editions Mardaga, Wavre, 2007, p. 37, quoted at http://ligaoamenilordeculturabontideni.blogspot.com/2012/02/pasiunile-siretorica-de-la-aristotel.html, accessed: January 6, 2020.
}

${ }^{4}$ Patrick McCreless, op. cit., p. 22. 
emphasized that music is able to elevate, correct, transform and appease passions, while later, Johann Mattheson (1681-1764) theorized that the purpose of music is to elevate the soul and open it to the communication with God ${ }^{1}$.

Athanasius Kircher (1602-1680) was the first to introduce the terms of the rhetorical structuring process, inventio, disposition and elocutio, in the list of musical rhetorical formulas. More exactly, inventio refers to the musical adaptation of the text, dispositio to the expressiveness between music and text and elocutio to the ornamentation of the composition through rhetorical figures and tropes ${ }^{2}$.

Although all the composers of the time agreed that musical rhetoric is a science of figures (Figurenlehre - in Burgmeister's theorizations), the number of melodic formulas differed from one author to another and, implicitly, so did the number of affects to be expressed. Tomas Baltazar Janovka (1669-1741) emphasized the importance of the expression of affects, Johann Georg Ahle (1651-1706) centred on the rhetorical figures of speech, Wolfgang Caspar Printz (1641-1717) started from ornamentation and Christoph Bernhard (1628-1692) regarded the use of dissonances as a priority ${ }^{3}$. Obviously, differences of opinion also appeared when a certain rhetorical figure had to be placed in a certain category. Joachim Burmeister defined three categories: harmonic figures (figurae harmoniae), melodic figures (melodiae) and harmonic-melodic figures (tam harmoniae quam melodiae). His categories follow the rhetorical classification of figures, distinguishing between those applied to the word in its individuality (figurae dictionis, or verbis) and those that express an entire sentence or structure (figurae totius orationis, sermonis, or sententiarum). Thus, Burmeister draws a parallel between the rhetorical figures associated with the word and melody, on the one hand, and those associated with the sentence and harmony, on the other. For example, figurae harmoniae are applied to all the voices in a composition, thus influencing the entire structure or harmony, just like the rhetorical figures applied to sentences 4 .

Composer Christoph Bernhard divided his rhetorical figures according to style: stylus gravis (prima pratica - the contrapuntal style of the Renaissance) and stylus luxurians communis (seconda pratica - the penchant for homophony of the Baroque). Johannes Nucius (1556-1620), a student of Lutheran Johannes Winkler's school of composition, in his theoretical work Musices Poeticae (1613), classifies rhetorical figures into two categories, based on the content and functionality of the respective formulas: figurae principales and figurae minus principales, a classification later adopted by Joachim Thuringus, Athanasius Kircher and Tomas Baltazar Janovka. Nucius distinguishes between the figures that are essentially instruments

\footnotetext{
${ }^{1}$ Idem, p. 29.

2 Idem, p. 76.

${ }^{3}$ Idem, p. 96.

${ }^{4}$ Idem, p. 97.
} 
of musical technique and those that are more strongly related to the text and affective-expressive rhetoric ${ }^{1}$.

In conclusion, the number, name and affect envisaged by certain musical formulas are not always the same in the treatises of the German theorists of the sixteenth to eighteenth centuries, but it is worth noting that over the centuries, the emphasis shifted from the importance of the text and message to be expressed, to the representation of the affects, to the detriment of the text, while composers such as Mattheson, Johann Adolf Scheibe (1708-1776) and Johann Nikolaus Forkel (1749-1818) stand as illustrative examples ${ }^{2}$.

\section{BIBLIOGRAPHY}

\section{BOOKS}

BARTEL, Dietrich, Musica Poetica, Musical-Rhetorical Figures in German Baroque Music, University of Nebraska Press, Lincoln and London, 1997

BURMEISTER, Joachim, Musica Poetica, translated by Agathe Sueur et Pascal Dubreuil, Editions Mardaga, Wavre, 2007, p. 37, quoted at

http://ligaoamenilordeculturabontideni.blogspot.com/2012/02/pasiunile-si-retorica-de-laaristotel.html

BUTT, John, Music Education and the Art of Performance in the German Baroque, Cambridge Musical Texts and Monographs, Cambridge University Press, Cambridge, 1994, xii, quoted by Helen Kin Hoi Wong, in Musica Poetica in Sixteenth-Century Reformation Germany, The Chinese University of Hong Kong, 2009

LORENZ, Ralph, Pedagogical Implications of Musica Practica in Sixteenth-Century Wittenberg, Ph.D. dissertation, Indiana University, 1995

\section{JOURNALS}

BUELOW, George, Symposium on Seventeenth-Century Music Theory: Germany, in "Journal of Music Theory 16", no. 1/2, quoted by Helen Kin Hoi Wong, in Musica Poetica in Sixteenth-Century Reformation Germany, The Chinese University of Hong Kong, 2009

FINSCHER, Ludwig (ed.), Die Musik des 15. und 16. Jahrhunderts, vol. 3, no. 1 of Neues Handbuch der Musikwissenschaft, ed. Carl Dahlhaus (Laaber: Laaber, 1989), p. 169, quoted by Helen Kin Hoi Wong, in Musica Poetica in Sixteenth-Century Reformation Germany, The Chinese University of Hong Kong, 2009

FISHER, Alexander, Music and religious change, in "The Cambridge History of Christianity Reform and Expansion 1500-1660", Edited by R. Po-Chia Hsia, Cambridge University Press, 2007

McCRELESS, Patrick, Music and Rethoric, in "The Cambridge History of Western Music Theory", ed. Thomas Christensen, Cambridge University Press, 2002, quoted at http://ligaoamenilordeculturabontideni.blogspot.com/2012/02/pasiunile-si-retorica$\underline{\text { de-la-aristotel.html }}$

${ }^{1}$ Idem, p. 100.

2 Idem, p. 23. 